\title{
Sustainable Customized Consolidation Design of Kuin Riverside Kampong Regeneration in Banjarmasin, Indonesia
}

\author{
Budi Prayitno, ${ }^{1, *}$ \\ ${ }^{1}$ Department Architecture and Planning, Faculty of Engineering Gadjah Mada University, Indonesia.
}

\begin{abstract}
On the one hand, the hyper-urbanization phenomenon gives numerous advancements in urban living quality, yet on the other hand, it also raises an equal amount of problems. Environmental issues come in the form of density issues, the existence of slums, floods, social inequality, and urban architectural identity. As a city with "City of a Thousand Rivers" as its brand, Banjarmasin now faces a shift in an urban architectural image from a river based city to a land-based city due to the rapid land-based infrastructure development. This resulted in the degradation of environmental and architectural quality of river-based village (kampong) settlement, the main component of Banjarmasin river front city, due to a strong paradigm shift. Kuin, a river side residential area/riverside tourist destination that is currently experiencing a degradation of environmental quality and place identity, is undergoing an urban renewal. Unfortunately, the policy approaches to urban planning that has been implemented are based on general formal guidelines; guidelines which do not take the informal nature of kampong river-side settlements, due to the lack of guidelines based on riverside place identity. This paper aims to explore the characteristics of riverside settlement using architectural image observation method, space syntax method for analyzing settlement configuration genotype, connectivity, interface and interlink territory integration, as well as questionnaire and interview methods to assess the perceptions of residents and municipal authorities. From the results of this research, five compositions forms have been identified: attachment to riverside settlement identity in the form of pilling, spanning, floating, embracing, and ascending with elements such as waterfront alleys, jukung (traditional boat), lanting (floating houses) as well as floating traditional markets that serves as the frame to the configuration. The identification process is done by using the approach of observing the spaceuse appropriation and the space-user perception on how to consider its sustainability aspect as a means to determine a level of adjustment. The result shows that self organized and self customized kampong residents and tourist are aware towards the river environment, the assets of local floating markets as well as the local social space. On the other hand, municipal authorities gave more attention to formal normative and regulative aspects. This analysis is used as the basis for recommendations for kampong riverside settlement design consolidation, which is done through guided participatory design workshops.

The result of this study is constructed as a concept for urban riverfront composition architecture, amphibious space territory, and urban riverfront settlement identity and expected to be able to further advance the knowledge surrounding the subject of urbanism and territoriality.
\end{abstract}

Keywords: customized consolidation, kampung regeneration, place identity, sustainability

\section{Introduction}

The place identity of an area is strongly determined by the attachment value of its social, economic, and environmental aspects. In its development the attachment value will always change in accordance with the architectural design trends of its era. The identity value of the area is currently at risk due to the strong development of contemporary styles and the complete disregard in the governance of the area. The identity of Banjarmasin as a city of a thousand rivers and the Venice of the East is currently experiencing a visual degradation. This is due to the area's aggressive land-based urban development. Rivers that initially amounted in the hundreds is now only a few dozens. Kuin as a region famous for its traditional floating markets is indicated to experience a decrease in value of its identity. This is indicated by the declining number of floating market traders, the number of incoming tourists, as well as the increase of housing density and the degradation of the quality of the river, which in turn affected riverside settlements. The land-based approach utilized by municipal regulation has side-lined local riverbased values.

Current local infrastructure development focuses more on dealing with existing problems due to negative impacts 
brought forth by previous approaches. The high demand for a fast development as well as the need for a future vision can only be realized by a positive outcome approach in a regeneration concept. There is also a need for various activities to be redefined as mixed-use and hybrids. This water regeneration model was developed in the $90 \mathrm{~s}$, characterized by a variety of development models with festivals and celebrating market placed as key magnets in commercial, housing, and recreational areas (Breen, 1994).

Place identity and place are widely viewed from various capital, commodity, marketing, culture and tourism aspects (Malone, 1996; Philo, 1993; Ward, S, 1994). The demand for creativity in devising place making is closely related to place marketing and investment to create jobs and increase space value (Philo, 1993). As part of place's identity, the architectural assets of waterfront areas need to be spatially reconstructed and calls for a reconstruction of their shape and ordering systems (Ward, 1994; Goodwin, 1997; Crilly, 1993). It is intended to answer the need for a customized consolidation of the development of various space uses, user, and territory integration needs as well as a sustainable consolidation on social interaction of productivity and environmental sustainability aspects.

\section{Customized Consolidation}

The interface territory of Kuin's riverside kampong settlement area, which will be reconstructed to answer the need for an improved visual quality that supports its place identity, is determined by the space connectivity, integration and appropriation values. The methods used in the reconstruction are 'redefine, reconnect, and revitalize'. The 'redefine' method is intended to define a new meaning for the place identity of Kuin's amphibious architecture. The 'reconnect' method aims to increase the value of connectivity and space integrity to support Kuin's space network and access. The 'revitalize' method is intended to formulate new dwelling, working, and access hybrid functions. Several ways that can be done to support architectural engineering is through territory attachment by manner of floating, pilling, spanning, embracing, and ascending. The reimagining of amphibious architecture is done through the mapping of perception of space identity from the stake-holders and agencies.

Space, territory and identity are composition architecture system that will be analyzed in assessing the level of sustainable consolidation that occurred in the Kuin region as a basis for constructing the amphibious regenerative village approach. Kampong riverside settlement or commonly called amphibious settlement because of its land and water elements, generally are self-organized, spontaneous, and organic in their growth. Processes that occurred by accident are not by design, which often causes social, spatial, environmental, and architecture problems. This is marked by the emergence of several phenomena namely high density, slums, floods, social inequality and architectural identity.

In addition to the negative impacts that emerged, commonly there are also hybrid and mix-used phenomena of various activities. The types that generally appear are based on the need for livelihoods resilience. Livelihood resilience, which is caused by economic development and creative trends, spawns hybrid types of mixed dwelling functions, mixed hybrid users between residents and tourists, hybrid bridges that synergize physical infrastructure assets, land status, and infrastructural assets environment.

The architectural methods to reinforce and respond to the quality degradation of place identity can be achieved through designing architectural tectonics. The architectural tectonics which can be processed in an attempt to re-imagine the degradation of identity quality are able to use constituent construction materials, as well as space composition and form composition concepts. 'Lanting' houses (floating houses), stilts homes, catwalks, jukung (traditional housing), and boat mooring docks are strong elements in the establishment of place identity in the Kuin area.

The reinforcing of place identity can be done on a local scale (area-based or citywide-based). Such spatial reinforcing methods are commonly done through space syntax simulations to assess connectivity and integration on a regional scale and the types of spatial relationships in building genotypes. The space syntax method can be used as a basis for establishing intra-network (area-based network) and inter-network (citywide-based) place identity reinforcement. This network configuration is determined by the space appropriation of various activities, space use appropriation and space intelligibility.

\section{Research Methods}

This research uses case study method with rationalistic paradigm. Research area with delineation of residential area and traditional floating market in Muara Kuin Village is on the banks of the river Kuin. The research method used is visual observation, space use mapping, questionnaire, and guided participatory design workshop. Visual observation observes objects forming the identity of an area. Space use mapping is done by using space syntax method. The assessment of the perceptions of space users and space management actors are put through the questionnaire method that the results are validated through guided participatory design workshop. The subjects for the questionnaire were taken by purposive sampling; 30 local residents respondents, 30 tourist respondents, and 30 municipal employees. Respondents are allowed to select more than 2 choices regarding the aspects that are considered important in the questionnaire. The topics include perception towards place identity, perception towards regeneration sustainability, and perception towards amphibious appropriate composition.

\section{Intra-place Attachment in Kuin}

Waterfront regeneration generally constructs places that are bound to local identity. The production of this place identity is packaged and marketed as a commodity (Goodwin, 1997). The identity of the waterfront area is linked to the effort to create a marketing brand for a place (Ward and Gold, 1994). Waterfront place identity development is closely related to the level of attachment and strength of the existing image. As a spatial and shape art, Architecture has to be able to integrate place construction and place marketing into a product that suits the needs of space use and users (Crilley 1993: 235). The 
visual clarity of a place identity can be used as a basis for creating architectural images. The development of a waterfront area is a part of urban transformation on a wider scale. The themed, scripted and branded concept of place making is a result of the transformation of the waterfront region (Hannigan, 1998). The attachment value of place making in Kuin is largely determined by visual perceptions that are deemed important by citizens, tourists and municipal employees. The value of this perception should be based on a measurable planning and participation process (Hague, 2005, Nanzer, 2004). Hence the process of formulating perception is done in a participatory manner through a design workshop to validate the results of the questionnaire. The Kuin brand as 'The Thousand of Rivers' and 'The Venice of The East' is the identity of the city of Banjarmasin. However, the relationship between the city and its identity must be seen from the value of its space intelligibility (Proshansky, 1978). The attachment value of this place is largely determined by the connectivity and space integration values.

Therefore the assessment of place attachment should be judged both from place-based perception and spacebased intelligibility. The diversity of perceptions towards place identity and space attachment is the embodiment of the symbols of the space fabric of the region (Hull, 1994; Patterson, 2005; Manzo, 2013).

\section{Hybrid Customized Consolidation}

Along with the decline of the space value there are also an increase in diversity of space use and self-organized users. The diversity of these activities is triggered by the diversity of existing livelihoods and tourism activities. A living space that is composite with the trade functions and tourism produces a hybrid form of customized consolidation. Hybrid customized activities can be seen from hybrid space, activities and governance aspects (Cho, 2016; Prayitno, 2017). The existence of this hybrid architecture adds value to the diversity of space and enhances the diversity of interactions. This process results in a much-found space structure in informal urban settlement areas in the form of co-existence space, coworking activities, and co-benefit governance (Prayitno, 2017). The architectural form of the existing spatial construction in Kuin has also undergone a customized hybrid process that combines the floating, pilling, embracing, spanning, and ascending forms that are composed in the amphibious settlement area.

\section{Kuin Amphibious Regeneration}

Kampong

The attachment value of an amphibious territory determines the place identity of an area. The attachment of floating markets, which are place identities, is determined by the value of connectivity and space integration. The process of self-organized and selfcustomized kampong residents and tourist with local floating market assets is an interaction of a local social space. Local governments also greatly influence the quality of this place identity because they have the authority in the process of regulation and governance. Therefore the reinforcing of place identity has to be done by manner of sustainable governance approach by the municipal government.

The government's approaches generally are responses to negative impacts rather than positive outcomes of development (Karmona, 2010). Hence the concept of regeneration becomes very important in the effort to redefine, reconnect, revitalize, reconstruct, and re-imagine. To redefine is to reconstruct the remainder of the riverside settlement. To reconnect is to construct a link for spatial asset access that forms place identity. To revitalize is to create new hybrid functions to reinforce dwelling, working and access functions. To reconstruct is to create the floating, pilling, embracing, spanning, and ascending composition structures.

\section{1. floating}

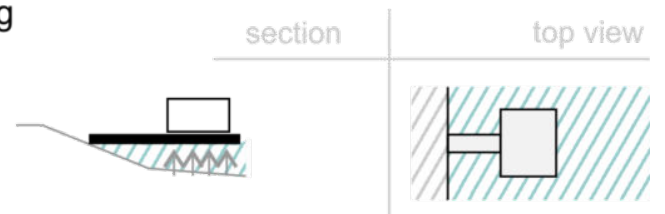

2. piling
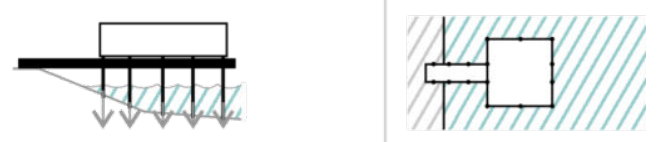

3. embracing
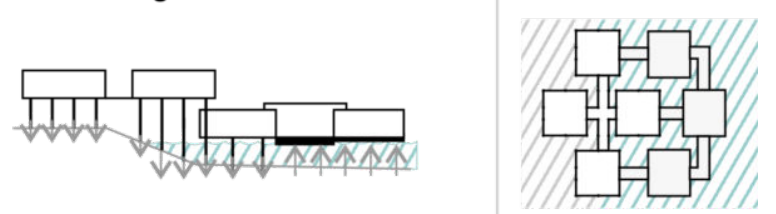

4. spanning
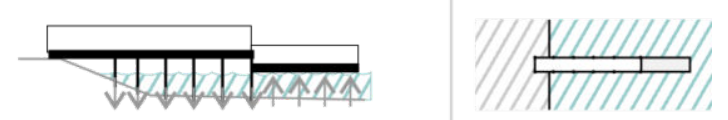

\section{5. ascending}
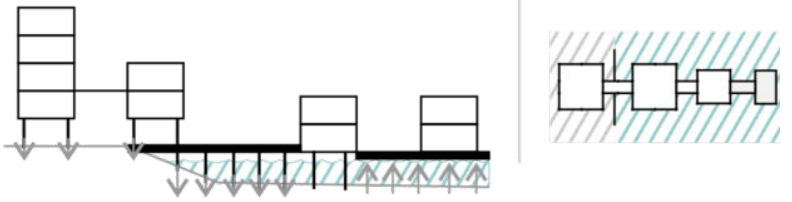

Fig. 1. Typology of Amphibious Space Composition.

To re-imagine is to create a contemporary architectural image for residential, commercial, and tourism functions in the context of amphibious composition identity.

\section{Discussion}

Based on the results of visual observation, it can be identified that the elements of Kuin riverside's place identity are the floating market, traditional boats boat, lanting traditional floating houses, traditional waterfront alleys, historic mosque, and traditional festivals. 


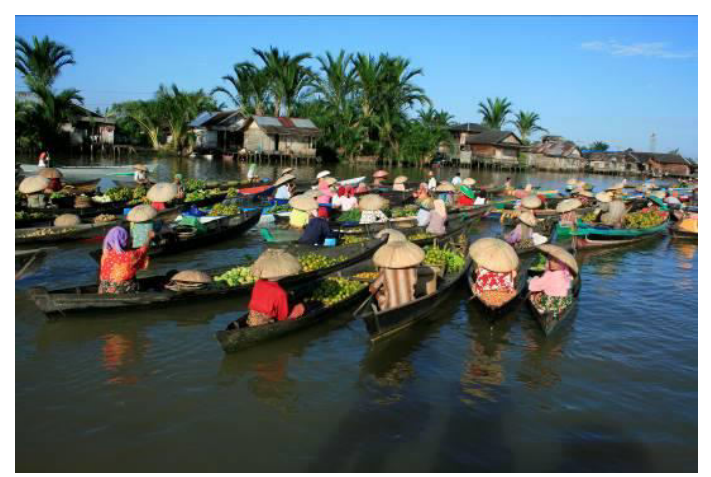

Fig. 2. Floating Market.

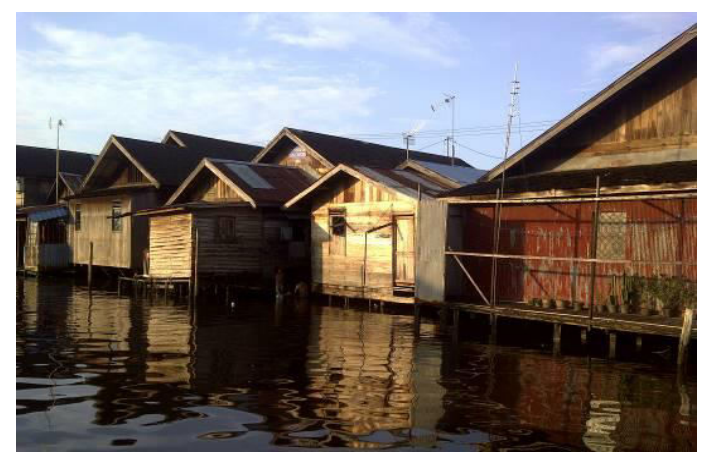

Fig. 3. Lanting Traditional Floating houses.

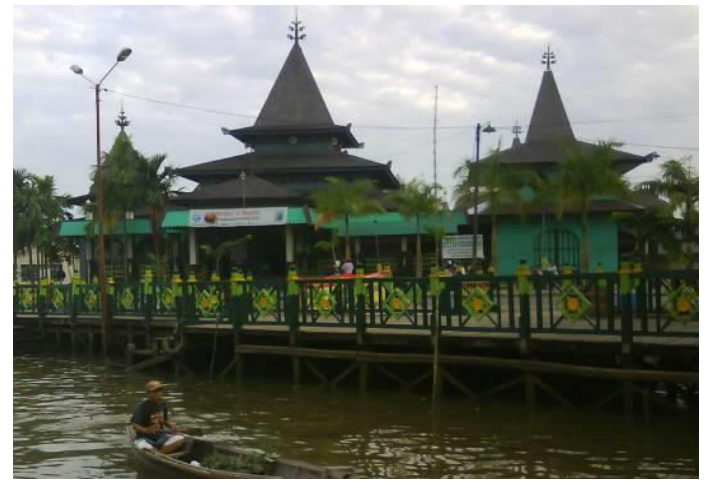

Fig. 4. Historic Mosque .

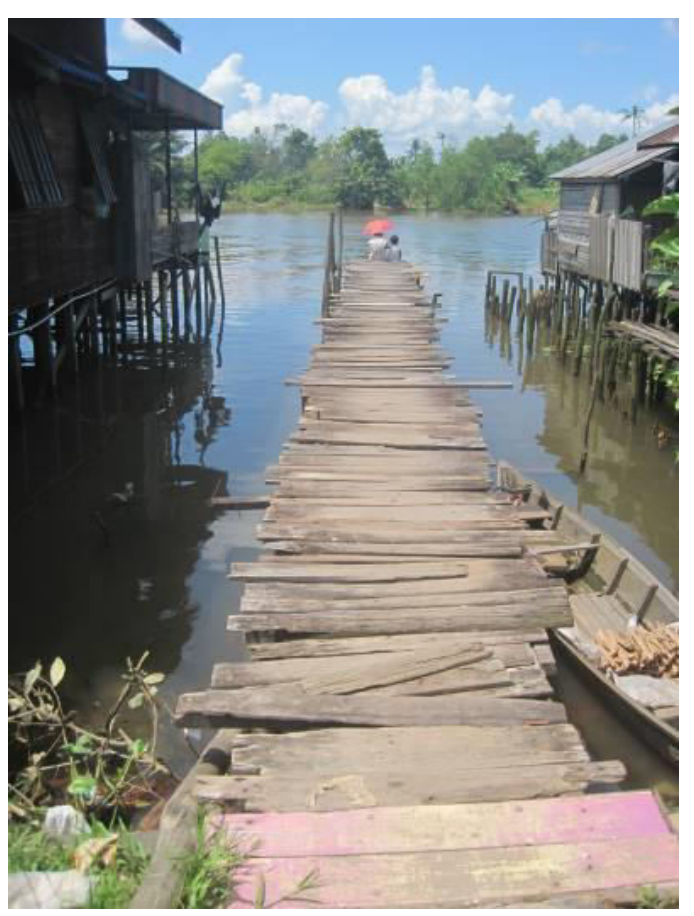

Fig. 5. Traditional Waterfront Alleys.

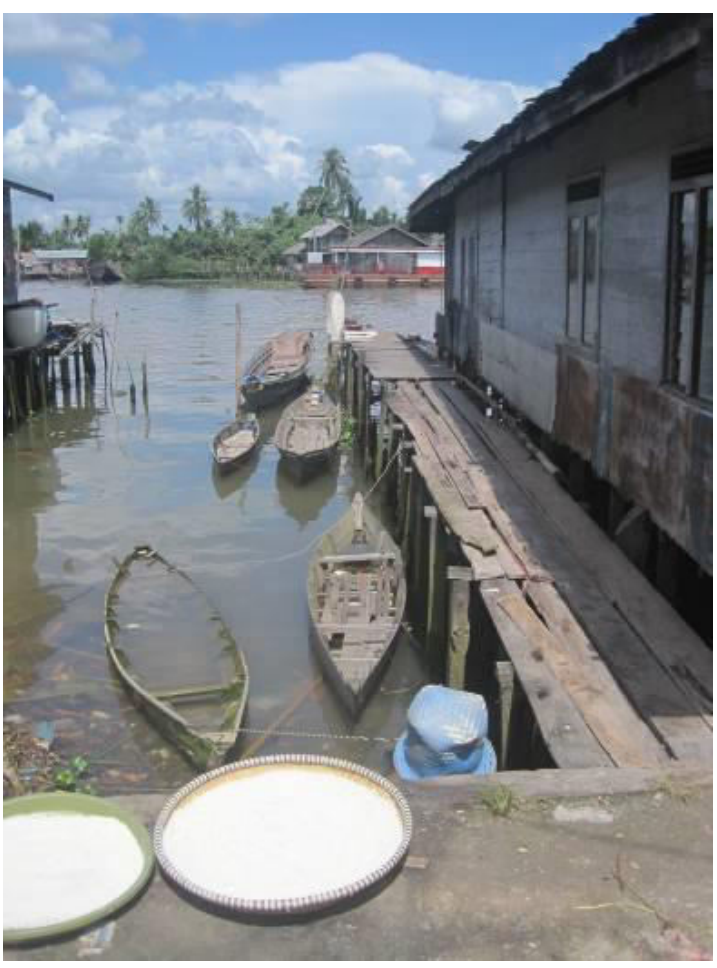

Figure 6. Jukung Traditional Boats. 


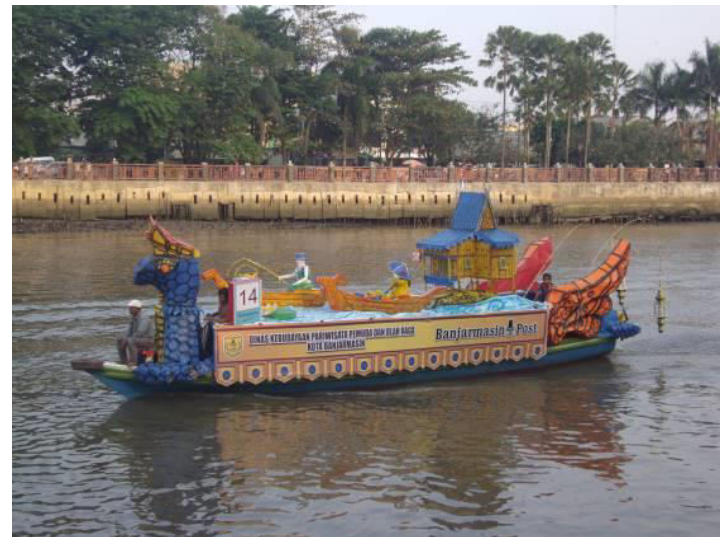

Fig. 7. Traditional Festivals

This visual observation was carried out in a participatory manner either through field surveys, or through participatory design workshops. The assessment through questionnaires and validations from the workshop have identified that there exists different perceptions of place identity.
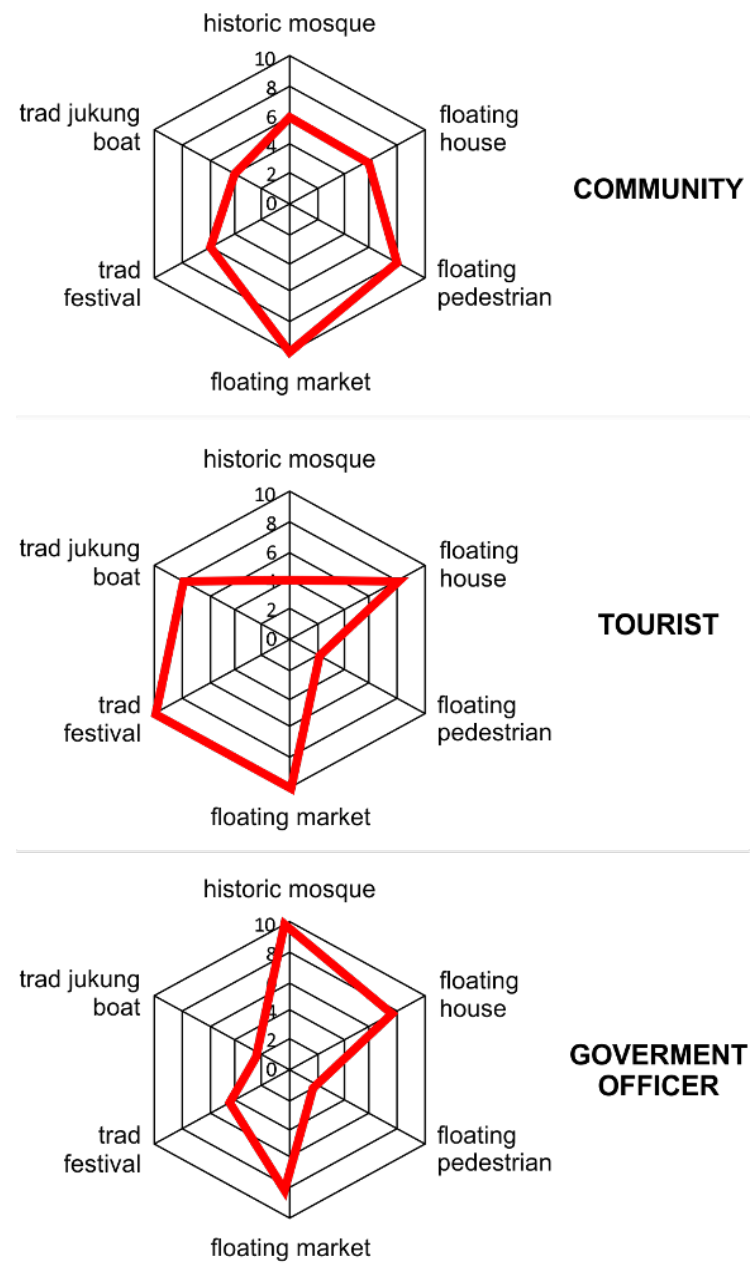

Fig. 8. Perception of Place Identity.

According to the tourists and the local community, floating markets is the main identity, while on the other hand the government officials viewed the historic mosque as the main identity. Tourists view that traditional festivals, floating houses, and jukung traditional boats are also an identity of the region (aside from floating markets), whereas the historic mosque is not. The local community sees waterfront pedestrian alleys, the historic mosque and traditional festivals are important identities while jukung traditional boat is not. Tourist also agreed that floating houses and traditional jukung are important identities and that the historic mosque and floating pedestrian are not. last but not least, government officials perceives floating houses and the floating market as an important identity while floating pedestrian, traditional boats and traditional festival are less important.
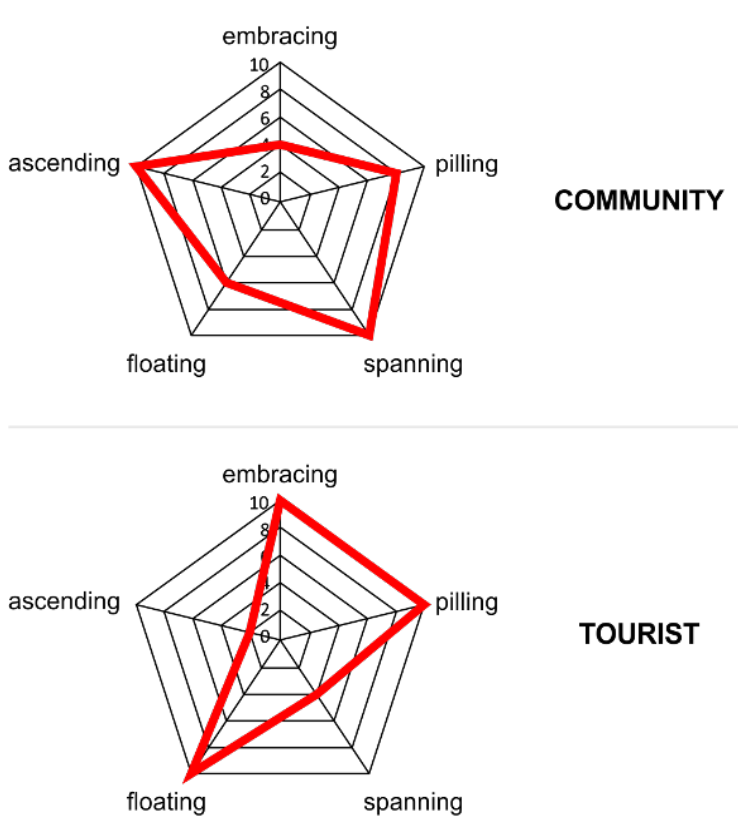

TOURIST

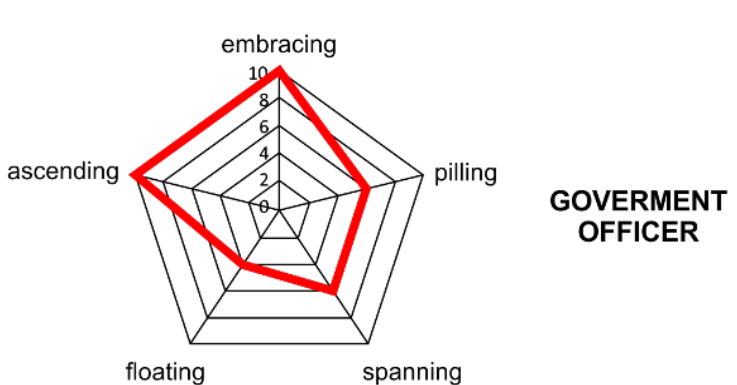

Fig. 9. Perception of Amphibious Appropriate Composition.

Based on the amphibious appropriate compotition aspect, the community considers spanning and ascending space constructions to be the most appropriate. Meanwhile, tourist views floating, pilling, and embracing space construction to be most appropriate. Government officials on the other hand sees ascending and embracing as the most suitable. Ascending is considered to be the most inappropriate method by tourists. Last, floating is considered to be the least appropriate method by government officials. 

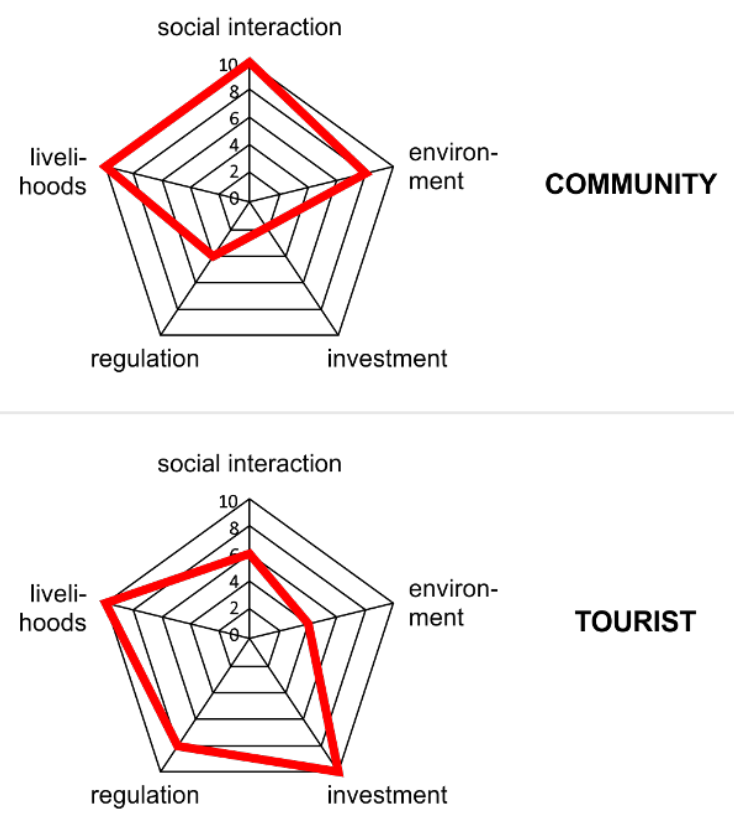

TOURIST

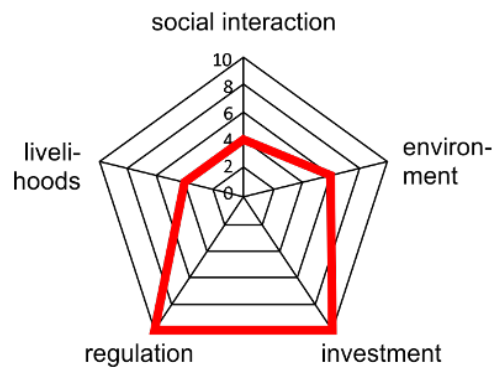

GOVERMENT OFFICER

Fig. 10. Perception of Regeneration Sustainability.

The community views livelihoods and social interaction as the most important deciding factor from the perspectives of the regeneration and sustainability aspect. Tourists on the other hand put livelihoods and investment at the front, while government officials see regulation and investment as the most important deciding factors.

The differences in the perception of respondents (community, tourists and government employees) after validation through participatory design workshop lay in the basis of consideration in determining the value of each interest. Local community respondents consider aspects of livelihoods and economic affordability to be the basis of their main assessment, whereas tourists view attractiveness and market value the basis for their primary assessment. Government officials on the other hand view regulation, investment and ease of implementation at the forefront.

Based on the observation on the intensity of space use and simulation of space syntax it was identified that connectivity and space integration occur on a local level. This is due to the strong space attachment value of the values of local place identity. Attachment towards intra-based local territories cannot be up scaled and replicated on a global scale. The results of global connectivity and integration values are very low.

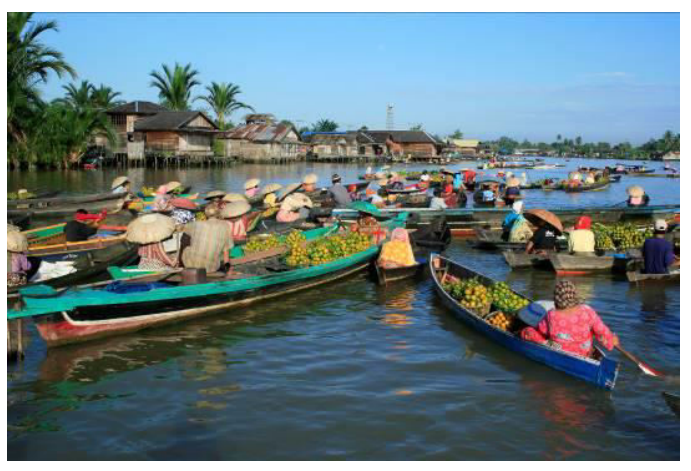

Fig. 11. Traditional Floating Market.

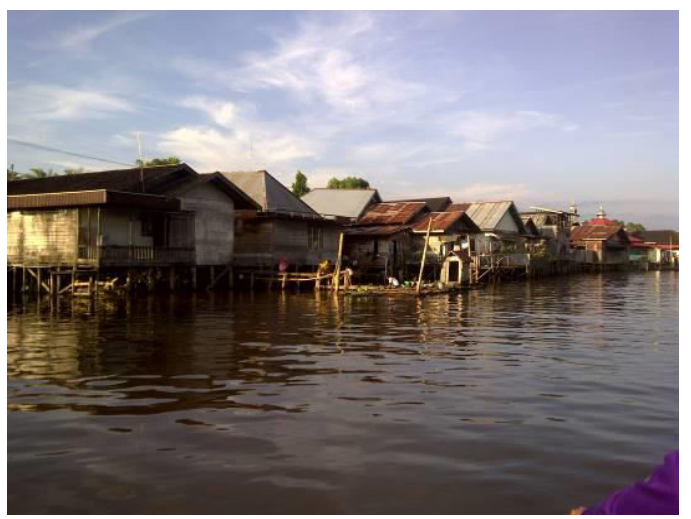

Fig. 12. Riverside Settlements.

Traditional floating market and riverside settlement integrated with historic areas (historic mosque and traditional festivals) have a very strong place attachment that cannot be scaled-up to citywide scale. Therefore, the process of consolidation and regeneration can only be sustained on a local scale. This is demonstrated by the diversity of spatial and building patterns that are responsive to the diversity of contemporary hybrid functions, which are done in adaptive, self-organized and, self-customized manner by the local community, tourist and municipal employees.

From the analysis of axial lines on global integration values, it was identified that the region has a low value. The relationship in the area is considered to be lacking, as seen in the scatter diagram value $\mathrm{R} 2=0.088$.

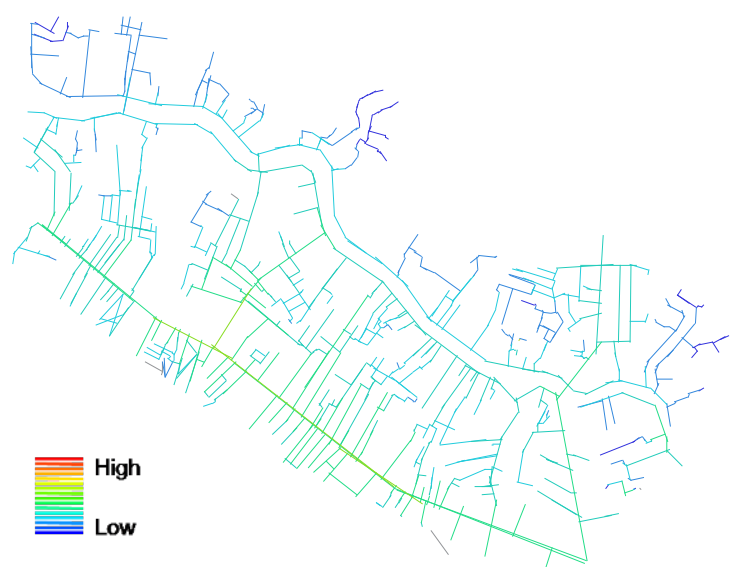

Fig. 13. Existing Global Integration Value 


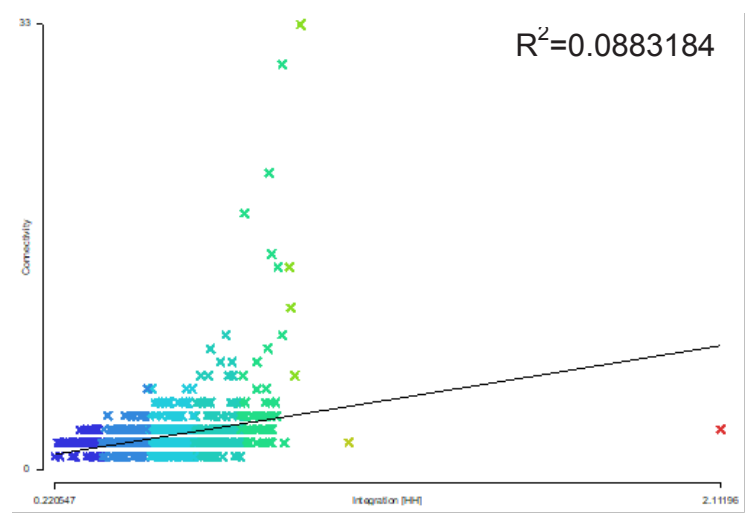

Fig. 14. Relationship Between Global Integration an Connectivity

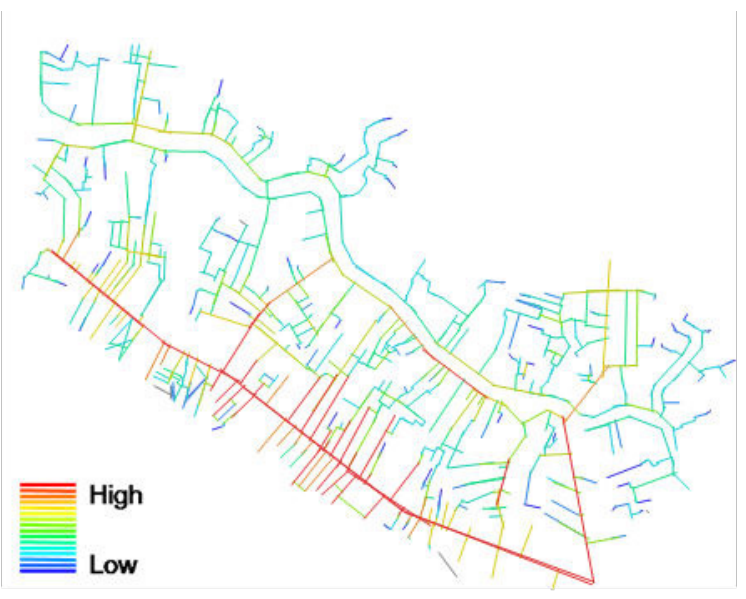

Fig. 15. Existing Local Integration Value

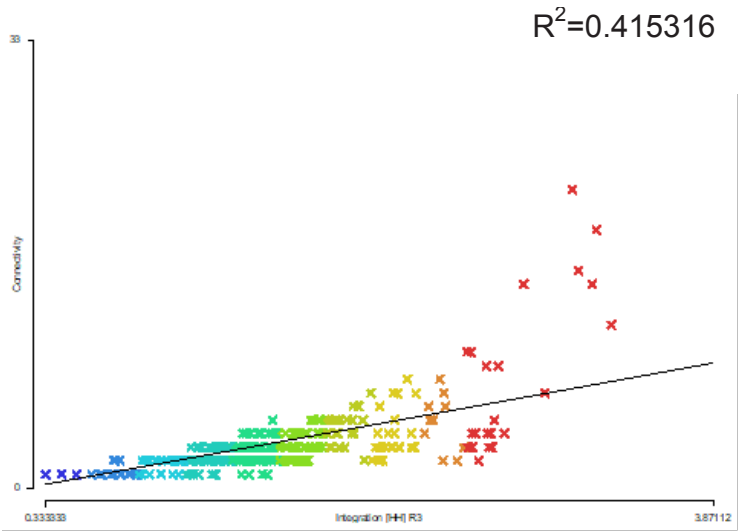

Fig. 16. Relationship Between Local Integration and Connectivity

It means that the accessibility value of the area with larger scale in Banjarmasin is low and difficult to reach from the city's network.

From the result of the analysis on space connectivity and integration of Kuin area through space syntax simulation, it is shown that the existing condition of Kuin area is much stronger locally $(\mathrm{R} 2=0,41)$ and globally integration $(\mathrm{R} 2=0,088)$ compared with its connectivity and integration on an urban scale (R2=0,017).

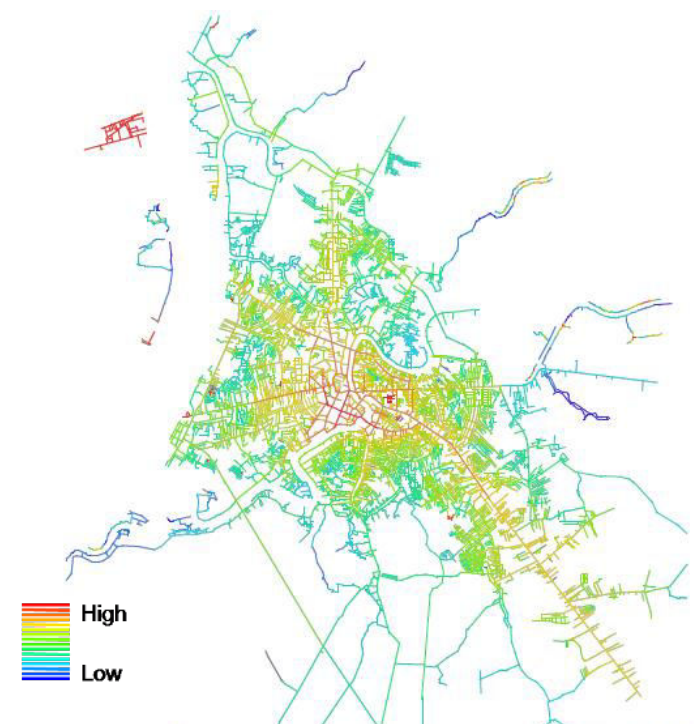

Fig. 17. Existing Citywide Value

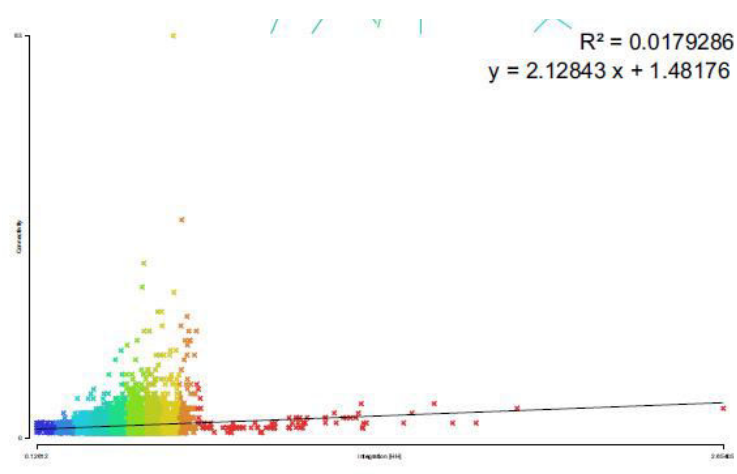

Fig. 18. Relationship Between Existing Citywide Global Integration and Connectivity

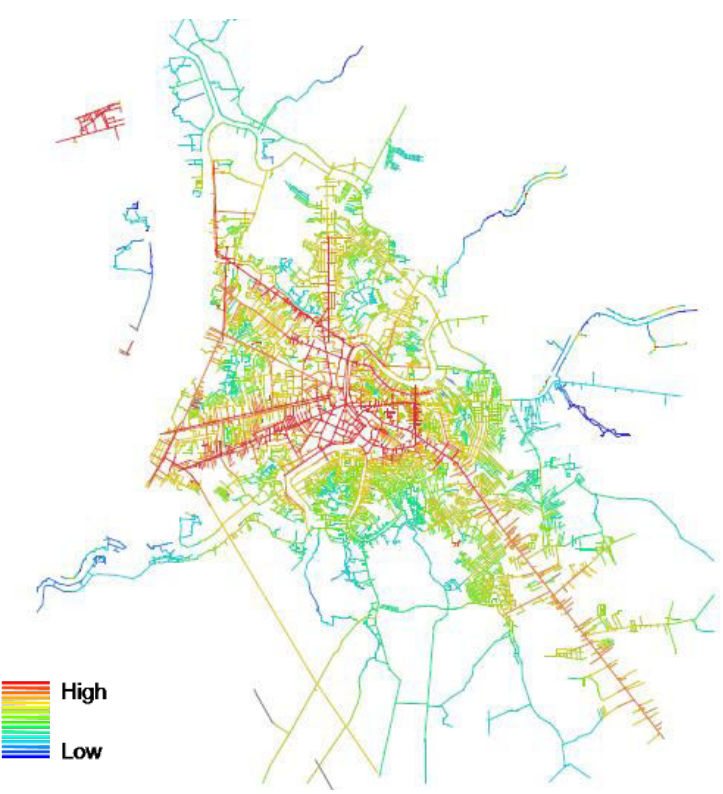

Fig. 19. Proposed Citywide Value 


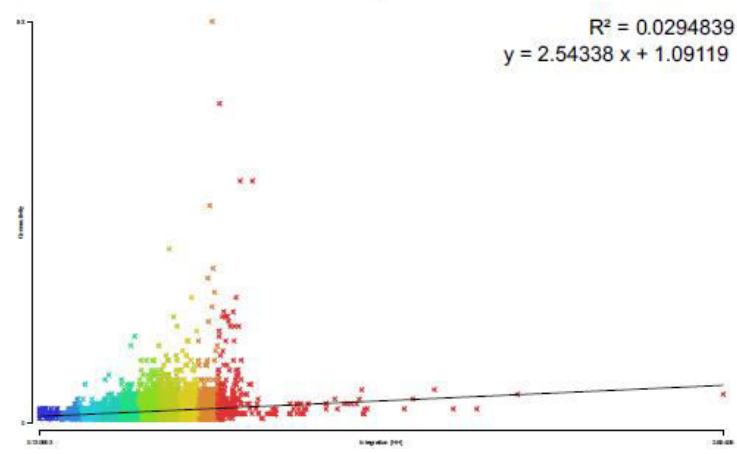

Fig. 20. Relationship between proposed citywide global integration an connectivity

Even when the connectivity is consolidated through trigger areas such as public open space, commercial, etc, its increase is not quite significant $(\mathrm{R} 2=0,029)$, which is only 0.012 .

Judging from the comparison between local and global integration values, the current development of the river Kuin is still localized, meaning that its development has not been integrated into the city system and its development is only influenced by local values. By taking the comparison between high local integration value and global integration value as a basis, it can be interpreted that the area has a strong area value, seen from both social and land use aspects. However the weakness of a strong local integration value is that the region becomes separated from the city's developmental system, which lags the area's growth.

\section{Conclusion}

The study finds that changes in urban development trends and shifts in development paradigms in Kuin have led to hybrid diversity of riverside settlement villages. This diversity is formed in a sustainable customized consolidation. Consolidation represents the transformation of space use and perception of spaceusers and agencies. The existing spatial configuration can have place identity reinforced in an intra-network. This is because the forming elements of place attachment in Kuin cannot be up scaled or replicated elsewhere. The place attachment that occurred has changed its image due to the emergence of multiplicity activities and users who each conduct customized consolidation.

The existing amphibious architecture that is constructed through spanning, floating, embracing, pilling, and ascending are composed with local elements (titian, lanting, floating market, and jukung). The hybrid and mixed-use compositions that combined residential, occupational, and recreational functions are a form of residential regeneration village that was achieved through the redefine, reconnect, revitalized, reconstruct and re-imagine approaches.

\section{References}

Breen, A. \& Rigby, D. (1994). Waterfront Cities Reclaim Their Edge. New York, NY: Mc Graw Hill.
Carmona, M., Heath, T., Oc,T. \& Tiesdell.S. (2010). Public Space, Urban Space. London : Routledge.

Cho, I., Heng, K., \& Trivic, Z. (2016). Re-Framing Urban Space: Urban Design For Emerging Hybrid and High-Density Conditions. New York: Routledge.

Crilley, D. (1993). 'Architecture as Metaphor'. in : Kearns, \& Philo, Selling Places. 231-252.

Dovey, K. \& Sandercock, L. (2002). Hype and Hope : Imagining Melbourne's Docklands, City, 6(1). 83101.

Goodwin, M. (1993). The City as Commodity. in : Kearns,G. \& Philo, C. (eds) Selling Places, Oxford : Pergamon. 145-162.

Hadinata, I. Y. (2010). Tipomorfologi Kota banjarmasin. Yogyakarta: Universitas Gadjah Mada.

Hague, C. and Jenkins,P. (Eds). (2005). Place Identity, Planning and Participation. New York: Routledge.

Hannigan,J. (1988). Fantasy City. London: Routledge.

Heldiansyah, J. (2010). Kajian Peningkatan Kualitas Lingkungan Binaan Tepian Sungai Kota Banjarmasin. Yogyakarta: Universitas Gadjah Mada.

Hull, B.R., Lam., \& Vigo,G. (1994). Place Identity: Symbols of Self In The Urban Fabric. Landscape and Urban Planning, 28, 109-120

Lynch, K. (1969). The Image of The City. Cambridge. Massacht: MIT Press.

Malone, P. (ed) (1996). City, Capital and Water. London: Routledge.

Manzo,L.C. (2013). Place Attachment: Advances in Theory, Methods and Application. Routledge, London \& Wright,P.D.

Mentayani, I. (2001). Karakteristik Perumahan Tradisional di Tepi Sungai. Makassar: Universitas Hasanuddin.

Mentayani, I. (2013). Transformasi Adaptip Permukiman Tepi Sungai di Kota Banjarmasin; Kasus: BaritoMuara Kuin, Martapura dan Alalak. Yogyakarta: Universitas Gadjah Mada.

Moore, C.W. (1994). Water and Architecture. London: Thomes and Hudson.

Nanzer,B. (2004). Measuring Sense of Place : A Scale for Michigan. Administrative Theory and Praxis 26(3), 362-382

Patterson,M.E., \& Williams, D.R. (2005). Maintaining Research on Place : Diversity of thought and scientific progress. Journal of Environmental Psychology, 25, 361-380.

Philo, C. \&. Kearns, G. (1993). 'Culture, History, Capital'. in : Kearns,G. \& Philo, C. (eds) Selling Places, Oxford : Pergamon, 1-32.

Prayitno, B. (2013). An Analysis of Consolidation Patterns of Kampong Alley Living Space in Yogyakarta, Indonesia. Journal of Habitat Engineering and Design, 99-112.

Prayitno, B. (2017). Integrated Sustainable Kampong Hybrid in Code Riverside Settlement in Yogyakarta, 
Indonesia. The 3rd International Conference on Engineering of Tarumanegara. Jakarta: Tarumanegara University.

Prayitno, Budi. (2012). A Morphological Analysis on Changing Patterns of the Banjarmasin Rivercity, Indonesia. Journal of Habitat Engineering and Design, 4(1). 23-32.

Prayitno, Budi. (2013). Analisis Permibilitas Keruangan dan Dinamika Fluida Angin dan Suhu Kawasan Permukiman Tropis Sungai di Banjarmasin. Jurnal Manusia dan Lingkungan, 20(2). 199-212.

Proshansky, H.M. (1978). The City and Self-identity, Journal of Environment and Behaviour, 10, 57-83.

Stedman, R.C. (2002). Toward A Psychology of Place: Predicting Behavior From Place-Based Cognition, Attitude, and Identity. Environment and Behaviour, 34(5), 561-581.

Torre, L.A. (1989). Waterfront Development. New York. NY: Van Nostrand Reinhold.

Uzzel,D., Pol,E. \& Badenas,D. (2002). Place Identification, Social Cohesion, and Environmental Sustainability, Environment and Behaviour, 34(1), 26-53.

Ward, S. \&. Gold,J. (eds). (1994). Place Promotion, Chichester:Wiley.

Yin, R. K. (2003). Case Study Research: Design and Method Third Edition. London: Sage Publication. 